\title{
Breastfeeding friendly airport to support healthy tourism
}

\author{
Lina Handayani ${ }^{1}$, Arzani ${ }^{2}$, Mahayu Agustia Jayanti ${ }^{3}$, Rini Puji Astuti ${ }^{4}$, Della Noviyanti ${ }^{5}$, \\ Maya Kusuma Dewi ${ }^{6}$ \\ 1,3,4,5,6Faculty of Public Health, Universitas Ahmad Dahlan, Indonesia \\ ${ }^{2}$ Nusukan Public Health Center, Surakarta, Indonesia
}

\section{Article Info \\ Article history: \\ Received Mar 11, 2019 \\ Revised Apr 25, 2019 \\ Accepted May 19, 2019}

\section{Keywords:}

Airport

Breasfeeding

Healthy tourism

Nursery room

\begin{abstract}
Motivation for breastfeeding and social support is very important for the success of exclusive breastfeeding. Breastfeeding support and motivation is obtained from family, leaders and the government. The implication of the government support given is the existence of regulations for organizer of public facilities that stating that the owner of public facilities must support the exclusive breastfeeding program at the airport. The airport is an important means for the mobility of both domestic and foreign tourist. The role of airport is very important to realizing healthy tourism. This study used a case study design. The subjects of this study were the leaders, staff and visitors of Adisutjipto International Airport. The number of informants is five people. The research instruments were interview guides and observation forms. Knowledge, attitudes and informant support for the exclusive breastfeeding program are good. There needs to be a stronger promotion effort for all levels of society so that exclusive breastfeeding programs can be achieved. Provision of nursery rooms at Adisutjipto International Airport is in accordance with government standards with facilities such as tables, chairs, baby boxes, washing stand, dispensers and trash can. Adisutjipto International Airport is confirmed as a breastfeeding friendly airport.
\end{abstract}

Copyright (C) 2019 Institute of Advanced Engineering and Science. All rights reserved.

\section{Corresponding Author:}

Lina Handayani,

Faculty of Public Health,

Universitas Ahmad Dahlan,

Jl. Prof. Dr. Soepomo, SH., Janturan, Warungboto, Umbulharjo, Yogyakarta, Indonesia.

Email: linafkm@gmail.com

\section{INTRODUCTION}

One indicator of the success of health development is a reduction in child mortality and an increase in community nutrition status. Indicators of child mortality are neonatal mortality, infant mortality (IMR) and under-five mortality rates. The infant mortality rate in Indonesia in 2017 is 24 per 1,000 live births [1]. The health profile of the Special Province of Yogyakarta in 2017 explained that the IMR in the Special Region of Yogyakarta reached 313 babies with the highest death cases in Bantul Regency, which amounted to 108 babies. The causes of infant mortality include low birth weight (LBW) and sepsis. One of the contributors to these deaths was inadequate breastfeeding [2].

Breast milk decreases the risk of acute infections such as diarrhea, haemophilus influenza, meningitis and urinary tract infections. The ingredients in breast milk also protect babies from future chronic diseases such as type 1 diabetes. Besides being beneficial for babies, breast milk is also beneficial for mothers, including restoring female fertility, reducing the risk of postpartum bleeding, breast cancer, pre-menopause and ovarian cancer. Exclusive breastfeeding can reduce infant mortality by $13 \%$ [3]. Exclusive breastfeeding is breast milk given to babies from birth to six months without adding food or other drinks except drugs and vitamins [1]. 
The coverage of exclusively breastfed babies in Indonesia in 2017 is $61.33 \%$, which has exceeded the 2017 Ministry of Health's strategic plan target of 44\% [1]. The health profile of the Special Region of Yogyakarta in 2017 explained that the coverage of exclusive breastfeeding in the Province of D.I Yogyakarta was $75.5 \%$ with the lowest coverage being in the city of Yogyakarta, which was $66.13 \%$ [2]. The extent of exclusive breastfeeding is influenced by several factors, one of which is the mother's motivation in giving exclusive breastfeeding. Motivation is the impulse that arises to start breastfeeding, maintain breastfeeding behavior and direct the behavior to the goals that the mother wants to achieve by breastfeeding her baby exclusively. Motivation comes from within individuals and from outside individuals [4].

Besides motivation, social support also influences the success of breastfeeding. Social support is the physical and psychological comfort provided by the people closest to an individual such as friends or family. Social support can be in the form of verbal or non verbal information or advice, real assistance or actions given to individuals. Social support has emotional benefits and behavioral effects for individual recipients of support [5]. Social support can be obtained from family, closest people even from the government [6]. This is stated in the Government Regulation of the Republic of Indonesia Number 33 of 2012 concerning Provision of exclusive breastfeeding which includes the government's responsibility in supporting exclusive breastfeeding programs. Government support in the form of guidance, supervision and evaluation of the implementation and achievement of exclusive breastfeeding programs in public places on a national, provincial and district/city [7].

The implications of the government support provided are the existence of regulations for organizers of public facilities. This regulation is stated in Government Regulation Number 33 of 2012 article 30, namely that the organizers of public facilities must support the exclusive breastfeeding program listed in paragraph 1. The provision of support provided is by providing special facilities for breastfeeding and/or milking the milk as stated in article 2. Public facilities as referred to in Article 30, one of which is an airport [7]. The airport is an important means for the mobility of both domestic and foreign tourists. The role of the airport is very important in supporting healthy tourism.

Based on existing empirical data from observations as well as the experience of the researchers themselves, facilities specifically for breastfeeding and/or milking breast milk are very necessary when doing tours. Especially for mothers when carrying babies. The existence of a nursery room is one of the factors that support the convenience of traveling.

\section{RESEARCH METHOD}

This type of research is descriptive qualitative research with a case study research design (case study). It aims to explore a case by collecting various sources of information through observation, interviews and document review. This research was conducted in March-October 2018 at Adisutjipto International Airport, located at Jl. Solo Km. 9, Maguwoharjo, Depok, Sleman, D.I Yogyakarta. The research subjects were five people consisting of leaders, staff, male visitors, female visitors not nursing mothers and female visitors who became nursing mothers. The tools and instruments used in the study were interview guides, checklists, voice recorders and stationery. Data collection was carried out by interviewing the subjects of the study and observations of the nursery room facilities at Adisutjipto International Airport.

\section{RESULTS AND DISCUSSION}

\subsection{Characteristics of respondents}

Respondents in this study consisted of five people including the Head of the Customer Service Division of PT. Angkasa Pura I, Staff Information Adisutjipto International Airport, male visitors, female visitors not nursing mothers and female visitors who are nursing mothers. Respondents have varied age, sex and occupational characteristics.

\subsection{Observations of nursery room}

Adisutjipto International Airport is an airport located in the Special Region of Yogyakarta on Jl. Solo Km 9, Maguwoharjo, Depok, Sleman. Adisutjipto International Airport has a passenger capacity of 1.2 million passengers per year by serving domestic and international flight routes. Adisutjipto International Airport has complete facilities starting from the departure terminal, Port Health Office (KKP) which is held directly by the Indonesian Ministry of Health, to shops. Including one of the facilities in it is a nursery room (Nursery room) which is located in each departure lounge.

Based on the results of observations, the facilities in the nursery room at Adisutjipto International Airport have met the requirements. The facilities for nursery rooms are shown in Table 1. 
Table 1. Facilities in the nursery room of Adisutjipto International Airport, 2018

\begin{tabular}{ccc}
\hline Variabels & \multicolumn{2}{c}{ Observations } \\
Yes & No \\
\hline Air conditioner (AC / fan). & $\sqrt{ }$ & \\
Sink with running water. & $\sqrt{ }$ & $\sqrt{ }$ \\
Bottle sterilizer. & $\sqrt{ }$ & \\
Hand washing soap. & $\sqrt{ }$ & \\
Chair with backrest. & $\sqrt{ }$ & \\
A table for changing clothes or diapers. & $\sqrt{ }$ & $\sqrt{ }$ \\
Baby box for babies who need sleep / rest. & & \\
Pillows to support the baby while breastfeeding. & $\sqrt{ }$ & \\
Tissue / hand wipe. & $\sqrt{ }$ & \\
Refrigerator. & $\sqrt{ }$ & $\sqrt{ }$ \\
Cold and hot dispenser. & $\sqrt{ }$ & \\
Washcloth to compress the breast. & $\sqrt{ }$ & \\
Closed trash can. & & $\sqrt{ }$ \\
Media for educational information counseling (posters, & & \\
photos, leaflets, booklets) about breastfeeding. & &
\end{tabular}

Table 1 explains that the facilities or completeness of nursery room at Adisutjipto International Airport have met the requirements according to existing regulations. Minister of Health Regulation Number 15 of 2013 concerning Procedures for Providing Special Facilities for Breastfeeding and/or Blushing of Mother's Milk states that the facilities in the nursery room consist of at least breast milk storage equipment and supporting equipment. Breastmilk storage equipment includes refrigerators for storing breast milk, cooling gel, bags for carrying breast milk and bottle sterilizers. While other supporting equipment includes tables, chairs with backrest, tool storage cabinets, hot and cold dispensers, bottle washers, closed bins, air conditioners, washcloths for compressing breasts, wipes/hand wipes, pillows to support the baby while breastfeeding [8]. Access to the nursery room at Adisutjipto International Airport has met the requirements. Means of direction to the nursery room have been provided but have not been maximized as shown in Table 2.

Table 2. Means for nursery room at Adisutjipto International Airport

\begin{tabular}{ccc}
\hline Variables & \multicolumn{2}{c}{ Observations } \\
& Yes & No \\
\hline Directions to the nursery room. & & $\sqrt{ }$ \\
Access to the nursery room is easy. & $\sqrt{ }$ \\
Room ID board. & $\sqrt{ }$ \\
\hline
\end{tabular}

Table 2 explains that the manager of Adisutjipto International Airport has provided a means of direction to the nursery room for visitors who want to access the space. Directions are usually in the form of signposts or placards. Signposts or placards are one of the facilities that must be provided in the public space as a means of information that can directly convey information to readers. Placard is considered very important because signposts provide instructions and information to visitors considering the location of the nursery room inside the terminal management office. Signposts that must exist in public spaces are usually in the form of Signage and Waydifing, which is a signpost programmed to direct humans to a place and help them reach the place [9]. The nursery room infrastructure of Adisutjipto International Airport is generally good. However, there are several variables that have not met the requirements as shown in Table 3.

Table 3. Infrastructure of nursery room at Adisutjipto International Airport

\begin{tabular}{ccc}
\hline Variables & Observations \\
& Yes & No \\
\hline Spacious room is 3x4 meters or according to the number of nursing mothers. & & $\sqrt{ }$ \\
Covered room with curtains / invisibility. & $\sqrt{ }$ \\
The door can be locked. & $\sqrt{ }$ \\
The door is easily opened and closed. & $\sqrt{ }$ \\
Ceramic / cement / carpet floor. & $\sqrt{ }$ \\
Adequate ventilation and air circulation. & $\sqrt{ }$ \\
Good lighting & $\sqrt{ }$ \\
Free of potential hazards (pollution free). & $\sqrt{ }$ \\
Calm and not noisy & $\sqrt{ }$ \\
Bright wall color. & $\sqrt{ }$ \\
\hline
\end{tabular}


Table 3 explains that the nursery room infrastructure of Adisutjipto International Airport in general has met the requirements. The area of the nursery room at Adisutjipto International Airport does not meet the requirements where the space is only enough for one breastfeeding person. According to Minister of Health Regulation Number 15 of 2013 concerning Procedures for Provision of Special Facilities for Breastfeeding and/or Reducing Breastfeeding, one of the health requirements of a nursery room includes a minimum of $3 \times 4$ meters of space or adjusted for the number of breastfeeding mothers. Based on observations made at the time of the study, there were many nursing mothers in the waiting room who needed a nursery room [8].

Supporting documents are not yet available in the nursery room at Adisutjipto International Airport. Supporting documents are usually in the form of a guest book. The guest book is a tool to record and find out the number of people who come to a place for reporting and evaluation in a certain period of time. The guest book is also used as a tool to monitor the visitor's progress in a place or customer in accessing a facility [10]. The guest book in the nursery room is used to find out how many visitors access the nursery room. The guest book in the nursery room includes information on the mother's name, baby's age, address, parent's job, impression/message for the nursery room. This information is used to evaluate and improve the quality of existing nursery room facilities and infrastructure.

Overall, the provision of nursery rooms at Adisutjipto International Airport has met the standards for the implementation of nursery rooms in public spaces. Rini et al. stated that most of the nursery rooms in Malang City had met the standards, but their use was still not effective. In order to maximize utilization, coordination from various sectors is needed to realize lactation space according to standards so that users are expected to obtain full benefits [11]. In contrast to Wijaya which states that the implementation of lactation space policies held by the public and private sectors in the Regency Purbalingga has not been implemented in accordance with the existing provisions. The incompatibility of the nursery room is due to the fact that the agency does not yet have internal rules regarding lactation space as a follow-up to Minister of Health Regulation Number 15 of 2013 [12]. Based on interviews with the Head of the Customer Service Section of PT. Angkasa Pura I, organizing nursery rooms as much as possible has been adjusted to existing standards to provide comfort and satisfaction for nursing mothers.

\subsection{Knowledge of respondents}

Knowledge in this study was measured through the ability of informants to answer questions from researchers regarding exclusive breastfeeding and lactation space. In relation to knowledge about the definition and benefits of exclusive breastfeeding, informants generally know. Based on the results of the interview, the informant explained that exclusive breastfeeding is the mother's milk which is first given directly by the mother to her child from the moon until the child is two years old without additional food. The Ministry of Health states that exclusive breast milk is breast milk given to babies from birth until the age of six months without providing food or drinks other than vitamins and drugs on the recommendation of health workers [13].

Regarding the benefits of exclusive breastfeeding, the informant explained that exclusive breastfeeding is beneficial for children's immunity, metabolism, growth and development of children, can make children healthier and smarter, and increase their level of closeness to their mothers. In addition to benefits for babies, from an economic standpoint exclusive breastfeeding is considered to reduce the cost of living. Nofi, et al. (2018) states that the benefits of giving are babies getting the nutrients and enzymes needed for their development. With the fulfillment of nutrition it will reduce the risk of stunting, children have a good immune system, prevent allergies, prevent disruption of the digestive and respiratory systems and can reduce the risk of obesity in infants. From an economic standpoint, exclusive breastfeeding clearly has the benefit of reducing spending to buy formula milk or baby food. The benefits of exclusive breastfeeding can also be felt by mothers because breastfeeding can reduce the percentage of maternal body fat so that the weight will be normal as before before containing [14]. In line with the research of Novita, et al. (2008) which states that infants who are exclusively breastfed have a higher IQ than babies who do not receive exclusive breastfeeding. This is because the length of breastfeeding influences the cognitive development of the baby [15].

In relation to government regulations governing exclusive breastfeeding, both visitors and leaders of Adisutjipto International Airport do not yet know. The provision of exclusive breastfeeding has been briefly mentioned in the Law of the Republic of Indonesia Number 36 of 2009 concerning Health articles 128 and 129. Article 128 describes exclusive breastfeeding and special breastfeeding facilities (lactation space). While Article 129 explains the role of the government in realizing exclusive breastfeeding programs, namely by making regulations. Government regulations related to exclusive breastfeeding are contained in the Republic of Indonesia Government Regulation Number 33 of 2012 concerning exclusive breastfeeding which includes in detail the relation to exclusive breastfeeding including the administration of nursery rooms. 
As a follow-up to the existing regulations, the Mayor of Yogyakarta specifically regulates through the Regional Regulation of Yogyakarta City Number 1 of 2014 concerning Exclusive Breastfeeding.

Based on the interviews conducted, the informant explained that the nursery room is a space specifically used by mothers to breastfeed their babies. As for the facilities and infrastructure of the nursery room, the informant responded that the nursery room facilities had been good, only less extensive and limited to chairs/sofas. Nursery room is a room equipped with breastfeeding infrastructure and milking milk which is used for breastfeeding babies, milking breast milk, storing breast milk and breastfeeding/breastfeeding counseling. Each organizer of public places or public spaces is obliged to provide nursery rooms including health service facilities, hotels/inns, recreation areas, land transport terminals, train stations, airports, seaports, shopping centers, sports buildings and others. the complete nursery room in public places is at least a table and chairs, a sink and hand-washing soap [8].

\subsection{Attitude of respondents}

Attitude is a predisposing factor. According to Lawrence Green's theory, attitude is one of the factors that determine behavior because it is related to perception, personality and motivation. The components of the attitude include the emotional, cognitive and behavioral components [16]. Based on the in-depth interviews that have been conducted, the informant explained that they agreed to the existence of exclusive breastfeeding given the important benefits for the mother and baby. Not in line with the research conducted by Astuti and Farah (2017) which stated that primipara mothers in Pundong Subdistrict, Bantul considered giving exclusive breastfeeding to babies was a troublesome activity so they chose to give formula milk to their babies. This can illustrate that maternal awareness and attitudes are very lacking [17]. Yuyun and Ngadiyono's research also stated that the mother's attitude towards the practice of giving exclusive breastfeeding was still relatively negative. Mother's attitude is influenced by emotional factors, mass media and personal experience factors. The emotional factor is the lack of support from the husband so that the motivation of the mother to breastfeed exclusively becomes less. The mass media factor is the incessant advertising of formula milk products that offer a variety of nutrients in milk that affect mothers to give babies formula milk to meet nutrition. Personal experience factors, namely the experience of mothers in children who previously were not given ASI, did not happen with their babies [18].

In addition, the informant also supported the existence of government regulations governing exclusive breastfeeding. Regulations related to ASI are considered to be positive government support for mothers. The creation of the Regional Regulation of Yogyakarta City Number 1 of 2014 concerning Exclusive Breastfeeding is one manifestation of government support for achieving exclusive breastfeeding programs, especially in D.I Yogyakarta. This regulation in detail reviews Exclusive ASI, organizing nursery rooms in public places and workplaces, even sanctions for public facilities providers if they do not support exclusive breastfeeding programs. In connection with government regulations regarding the operation of nursery rooms at Adisutjipto International Airport, informants were very supportive by procuring nursery rooms at both Adisutjipto International Airport and other public facilities. The informant explained that basically the nursery room is needed for nursing mothers and their babies to maintain the privacy and comfort of nursery room users.

\subsection{Support for exclusive breastfeeding programs}

Based on the interviews conducted, the informants explained that they strongly supported the existence of exclusive breastfeeding programs. This support is increasingly maximized given the benefits of breast milk which is very important for babies, coupled with the regulation of the government which specifically regulates exclusive breastfeeding. Support for nursing mothers is usually obtained from families, communities, workplace leaders and the government.

Family support is needed by the mother when caring for the baby. Family support in this case is obtained from husband, parents/in-laws and close relatives. Families in general are the closest group to individuals. So that the lack of support from the family can affect the attitudes and behavior of mothers in giving exclusive breastfeeding. If the family gives full support, the mother will be motivated, confident and passionate about giving exclusive breastfeeding to her baby [19]. Dewi's research (2015) states that mothers who have family support have the opportunity to give exclusive breastfeeding 4.222 times greater than mothers who do not support. This is because a mother who has a harmonious relationship with her family will have relatively good emotions. In the case of exclusive breastfeeding support, husbands can play a role in breastfeeding decision making, initiation of early breastfeeding and length of breastfeeding time [20]. Made et al. (2018) also said that good family support would make mothers willing to give exclusive breastfeeding [21]. 
Community support in this case is usually from Posyandu cadres. Posyandu cadres are tasked with providing ASI-related education for pregnant and lactating mothers. Posyandu cadres also played an active role in monitoring by visiting and educating directly pregnant women and nursing mothers to prepare exclusive breastfeeding. In addition to posyandu cadres, the activists of Family Welfare Development (PKK) also provided motivation in exclusive breastfeeding given that one of the main PKK programs was health and health planning [21].

The success of breastfeeding in the workplace is strongly influenced by the work environment created by the workplace environment. In this case the leader plays an important role in the success of exclusive breastfeeding programs in the workplace. Irni and Emi's stated that leaders who have good knowledge and abilities will want to negotiate with working mothers who breastfeed or will breastfeed. Leaders must provide motivation to mothers to attend breastfeeding prenatal classes and join ASI support groups. Motivation from leaders can increase the self-confidence of working mothers to breastfeed in the workplace in order to realize exclusive breastfeeding for working mothers. The support given by the leadership to working mothers who breastfeed is usually in the form of making policies, providing certain times for breastfeeding / milking the mother's milk and providing breastfeeding room facilities in the workplace [22].

\subsection{Breastfeeding friendly airport}

The management of Adisutjipto International Airport has maximally tried to provide lactation space. Provision of this nursery room is based on the principle of fulfilling customer rights or airport visitors. The nursery room at Adisutjipto International Airport is a form of social support to support the exclusive breastfeeding program being promoted by the government. The complete nursery room of Adisutjipto International Airport is a form of implementation of government regulations that have both facilities and infrastructure. Based on observations that have been made, the implementation of nursery rooms in general is in accordance with the standards. Research by Michael and Joan stated that in America, out of 100 airports with the highest passenger frequency, only $8 \%$ of airports provide minimum nursery room facilities such as tables, chairs and electrical sockets, $2 \%$ of airports provide space but have not met drinking water requirements because there are no electric desks and sockets, and $25 \%$ use family toilets as nursery rooms. However, $62 \%$ of airports in America are said to be breastfeeding friendly because they still provide clean, safe and comfortable family toilets. Family toilets have almost complete facilities including toilets, washbasins, mirrors, baby rest rooms, electric sockets and chairs [23].

\section{CONCLUSION}

The airport is very important for the mobility of tourists both domestic and foreign. The role of the airport is very important in supporting healthy tourism. Adisutjipto International Airport is confirmed as a breastfeeding-friendly airport. It has provided nursery rooms that are in accordance with the standards. Knowledge, attitudes and support of the leadership, staff and visitors regarding the exclusive breastfeeding program are adequate. However more promotion efforts are needed so that the program can be implemented by all levels of society.

\section{REFERENCES}

[1] Indonesia Health Minister, "Indonesia Health Profile 2017”, Jakarta: Ministry of Health of the Republic Indonesia. 2018.

[2] Public health office, "Health Profile of Yogyakarta Special Region in 2017”, Yogyakarta, 2018.

[3] Roesli, U., "Initiation of Early Breastfeeding Plus Exclusive Breastfeeding”, Jakarta: Pustaka Bunda, 2008.

[4] Nuryanti, L, Hadjam, N, "Effectiveness of the Breastfeeding Education Program for Pregnant Women to Increase Motivation to Give Exclusive Breastfeeding”, Jurnal Ilmiah Berkala Psikologi, Vol. 10, No. 1, pp. 40-57; 2008.

[5] Sarafino E. P., Smith T. W, Health Psychology: Biopsychosocial Interactions: 7th edition, New York: Wiley, 2010.

[6] Nurlinawati; Sahar, J.; Permatasari, H., "Family Support for Exclusive Breastfeeding for Infants in Jambi City", Jambi Medical Journal, Vol. 4, No. 1, pp.76-86, 2016.

[7] Indonesian State Secretariat, "Government Regulation of the Republic of Indonesia Number 33 of 2012 concerning the Exclusive Breastfeeding”, Jakarta: Indonesian Government, 2012.

[8] Indonesian Health Minister, "Regulation of the Minister of Health of the Republic of Indonesia Number 15 of 2013 concerning Procedures for Providing Special Facilities for Breastfeeding and/or Reducing Breast Milk", Jakarta: Ministry of Health of the Republic Indonesia, 2013. 
[9] Taufiq, S.A., Wulandari, R., "Effectiveness of Signage System Placement in the Bandung Railway Station Lobby", Idealog Journal, Vol. 1, No. 1, pp. 49-62, July 2017.

[10] Rushendi, "Digital Guest Book for Supporting User Services at the Balittro Library", Digital Library Spice and Medicinal Plant Research Center, 2010.

[11] Rini; Sasmito, C., Gunawan, C. I., "Implementation of Lactation Room Provision Policy in Malang City", AcTion: Aceh Nutritioun Journal, Vol. 3, No. 1, pp. 34-41, May 2018.

[12] Wijaya, P. S., Soesanto, "Study of Lactation Space Policy Implementation in the Government and Private Sector", Unnes Journal of Public Health, Vol. 6, No. 3, pp.196-202, July 2017.

[13] Indonesia Health Minister, "Infodatin: Exclusive breastfeeding situation and analysis", Jakarta: Ministry of Health of the Republic Indonesia, 2014

[14] Anggraeni, N., Pangestuti, D. R., Aruben, R., "Factors Affecting the Role of Breast Milk Motivators in Exclusive Breastfeeding", Public Health Journal, Vol. 6, No. 2, pp. 74-81, April 2018.

[15] Novita, L., Gurnida, D. A.; Garna, H.; , "Comparison of Cognitive Functions of Babies Aged 6 Months that Get and Who Don't Get Exclusive Breastfeeding”, Sari Pediatri Journal, Vol. 9, No. 6, pp. 429-434, April 2008.

[16] Soekidjo, N., "Health Promotion and Behavioral Sciences", Jakarta: Rineka Cipta, 2010.

[17] Astuti, E. P., Adhiba, F., "The level of knowledge of exclusive breastfeeding in Primipara's mother in Pundong Hamlet, Srihardono Sub-District, Pundong District, Bantul Regency”, Journal of Health, Vol. 4, No. 1, pp. 49-54, January 2017.

[18] Kohariningsih, Y. D., Ngadiyono, "Relationship Between Husband's Attitudes and Support with Exclusive Breastfeeding Practice for Mothers Not Working with Babies 7-12 Months in Ngemplak Simongan Community Health Center Working Area in West Semarang District", Midwifery Journal, Vol. 2, No. 4, pp. 43-50, April 2013.

[19] Hamidah, S., "Relationship Between Family Support and Exclusive Breastfeeding for Babies 0-6 Months", MIDPRO Journal, Vol. 8, No. 1, 2016.

[20] Damayanti, D.S., "Factors Associated with Providing Exclusive ASI to Workers' Mothers as Nursing Personnel in Pasar Rebo Hospital in 2010-2011", MH tamrin health scientific journal, Vol. 7, No. 1, pp. 21-27, January 2015.

[21] Wismantari, M. W. J., Suryawati, C., Arso, S. P., "Input Analysis and Environment of Breastfeeding Mothers Against Exclusive Breastfeeding Program (Case Study of Pandanaran Health Center in Semarang City", Public Health Journal, Vol. 6, No. 5, pp. 117-123 October 2018.

[22] Setyawati, I.; Sutrisminah, E., "The Importance of Motivation and Leadership Perception of Exclusive Breastfeeding Behavior in Working Mothers”, Sultan Agung Scientific Magazine, Vol. 50, No. 127, pp. 1-14, 2012.

[23] Haight M.; Ortiz J., “Airports in the United States: Are They Really Breastfeeding Friendly?”, Breastfeed Medicine Journal, Vol. 9, No. 10, pp.515-9, 2014 